\begin{tabular}{l|r|r}
\hline Jurnal Penelitian Farmasi Herbal & Vol. 2 No. 1 & Edition: May - October 2019 \\
\hline \multirow{2}{*}{ Received: 17 September 2019} & http://ejournal.delihusada.ac.id/index.php/JPFH & Accepted: 14 October 2019 \\
\cline { 2 - 3 } & Revised: 01 October 2019 &
\end{tabular}

\title{
PENGARUH EKSTRAK KULIT BUAH MANGGIS (Garcinia Mangostana Linn) TERHADAP PERISTALTIK ILEUM TERPISAH MARMOT JANTAN SEBAGAI ANTI DIARE
}

\author{
Zaim Anshari ${ }^{1}$, Chrismis Novalinda Ginting ${ }^{2}$, Linda Chiuman ${ }^{2}$, Yuliani Mardiati Lubis ${ }^{2}$ \\ ${ }^{1}$ Universitas Islam Sumatera Utara, Jl. STM No.77 Medan \\ ${ }^{2}$ Universitas Prima Indonesia, Jl. Sekip, Simp. Sei Putih, Medan \\ Email: zaim.anshari@fk.uisu.ac.id
}

\begin{abstract}
Objective: To determine the effect of mangosteen peel extract (Garcinia mangostana Linn) on ileal peristalsis separate male guinea pigs as diarrhea. Results: $t$-independent test, the difference: Contraction of ileum Acethlcholin with Atropine + Acethylcholin is 6.333 compared to Acethylcholin with extract + Acethylcholin is 8,500 with ANOVA test P-value meaning the difference between the two contractions of the ileum is significant. The t-independent test results are the difference: Contraction of ileum Histamine with Diphenhydramine + Histamine is 8.333 compared to Histamine with extract + Histamine is 10.833 with ANOVA test P-value meaning the difference between the two contractions of the ileum is significant. The results of the t-independent test are the difference: Contraction of the Barium ileum with Papaverine + Barium is 2,500 compared to the contraction of Barium ileum with extract + Barium is 2,500 with ANOVA test P-value meaning that there is no difference between the two contractions of the ileum. From the three experimental groups, it was concluded that the extract worked similar to Papaverine. Cecilia's study, fruit skin extract can be used as diarrhea in Daire Effect of Mangosteen Ethanol Extract of Oleum riciniinduced Webster Swiss Mice.
\end{abstract}

Keywords: Mangosteen Bark Extract; Ileum Peristalsis; Diarrhea

\section{PENDAhUluan}

Diare dan konstipasi sangat sering terjadi dan secara bersama -sama menimbulkan beban yang sangat besar dari segi mortalitas, morbiditas, terganggunya aktifitas sosial, berkurangnya produktifitas kerja dan konsumsi sumber daya medis. Berdasarkan data profil kesehatan Indonesia tahun 2010, diare akut karena infeksi dilaporkan sebagai penyakit yang paling sering menyebabkan rawat inap di Rumah Sakit dengan case fatality rate 1,79\% (Widiyati, 2014).

Pada tahun 2012, dari 559.011 orang perkiraan kasus diare yang ditemukan dan ditangani adalah sebanyak 216.175 atau $38,67 \%$, sehingga angka kesakitan (IR) diare per 1000 penduduk mencapai $16,36 \%$. Capaian ini mengalami penurunan dari tahun-tahun sebelumnya, yaitu 19,35\% pada tahun 2011 dan $18,73 \%$ pada tahun 2010. Pencapaian IR ini jauh di bawah target yang diprogramkan yaitu 220 per 1000 penduduk (Dinkes, 2016b). Adapun angka kesakitan Diare per 1000 penduduk dari 2.228.229 total penduduk kota Medan, diperkirakan 26.025 diantaranya menderita diare, perkiraan ini dihitung dengan berdasarkan angka morbiditas (kesakitan) diare nasional tahun 2016 yaitu 270 per 1000 jumlah penduduk (Dinkes, 2016a).

Diare biasanya ditandai dengan frekuensi defekasi yang berlebih jika dibandingkan dengan frekuensi normal, ditandai oleh konsistensi encer, bersifat akut dan kronis. Diare akut terjadi akibat infeksi yang disebabkan oleh bakteri, virus, amuba, maupun toksin bakteri yang mencemari makanan atau berkaitan dengan gangguan gastrointestinal (Evacuasiany, 2005). Diare dapat menyebabkan dehidrasi dan ketidakseimbangan elektrolit yang tidak jarang berakhir pada shock dan kematian terutama pada bayi dan anak-anak 


\begin{tabular}{c|c|c}
\hline Jurnal Penelitian Farmasi Herbal & Vol. 2 No. 1 & Edition: May-October 2019 \\
\hline & http://ejournal.delihusada.ac.id/index.php/JPFH & \\
\cline { 2 - 3 } Received: 17 September 2019 & Revised: 01 October 2019 & Accepted: 14 October 2019
\end{tabular}

kecil (Adnyana, 2004). Penyebab lain terjadinya diare adalah karena resorpsi yang melebihi sekresi (Tan, 2002).

Pengobatan yang dapat dilakukan dalam mengatasi diare adalah mencegah dan mengatasi dehidrasi serta kehilangan garam menggunakan garam rehidrasi oral yang mengandung senyawa obat-obat antidiare seperti papaverin dan oksifenonium (Tan, 2002). Pada masyarakat Indonesia, penggunaan obat-obat tradisional masih dominan digunakan dalam mengatasi diare. Pemanfaatan bahan herbal seperti rimpang kunyit (Hudayani, 2008), ekstrak etanol daun salam (Musdar, 2012), ekstrak etanol daun nangka dan daun angsana (Anas, 2016), infusa kulit batang jambu mede (Pamungkas, 2009), maupun ekstrak kulit buah manggis (Noviardini, 2010) sering dimanfaatkan masyarakat Indonesia dalam mengatasi masalah diare.

Salah satu obat tradisional yang dapat digunakan adalah kulit buah manggis tua. Budidaya buah manggis yang cukup besar berada di daerah kecamatan Lima Puluh, Kabupaten Asahan, Propinsi Sumatera Utara. Untuk mengobati mencret (diare), masyarakat Asahan menggunakan air rebusan kulit buah manggis yang tua tersebut. Ekstrak kulit buah manggis (KBM) banyak mengandung senyawa-senyawa bioaktif yang berefek farmakologi bagi tubuh seperti xanthon, flavonoid, triterpenoid dan benzofenon (Chin et al, 2008). Lebih lanjut, ekstrak KBM berpeluang dijadikan bahan obatobatan karena mengandung alfa mangostin dan gartanin (Rubiyanti, 2017) dan dari hasil uji fitokimia diketahui bahwa ekstrak KBM bereaksi sangat positif terhadap uji flavonoid, polifenol, dan saponin (Miryanti, 2011; Dewi, 2013).

Tanin memiliki efek antidiare adstringens yang dapat mengendapkan protein pada permukaan usus (Kumar, 1983). Keadaan tersebut dapat membentuk formasi lapisan (barrier) pada permukaan saluran gastrointestinal sehingga menjadikan permukaan usus lebih resisten sehingga terjadi perapatan sel terluar yang menghambat sekresi cairan dan elektrolit yang dikeluarkan ke dalam usus (Mutschler, 1991). Tanin golongan prosianidin mampu menghambat motilitas sehingga memperlama waktu transit usus (Galvez, 1991).
KBM mengandung senyawa xanton sekitar $123,97 \mathrm{mg} / 100 \mathrm{ml}$ (Yatman, 2012) dan resin yang hanya dihasilkan oleh genus garcinia seperti buah manggis yang sangat manjur untuk mengobati diare kronik pada anak dan disentri (Burkill, 1997; Noviardini, 2010; Putra, 2010). Khasiat lain dari senyawa xanton adalah sebagai penyegar sekaligus pencegah dan pengobat sejumlah penyakit seperti diabetes, kolesterol tinggi, serangan jantung, kanker, inflamasi, dan penuaan dini (Yatman, 2012). Berdasarkan penjelasan di atas, maka penelitian ini bertujuan untuk mengetahui apakah ada pengaruh ekstrak kulit buah manggis (Garcinia mangostana Linn) terhadap peristaltik ileum terpisah marmot jantan sebagai anti diare.

\section{METODE}

Jenis penelitian yang dilakukan adalah penelitian eksperimental in vitro dengan menggunakan metode standar dari magnus dengan rancangan penelitian controled experiment latin square. Penelitian dilakukan di Laboratorium Farmakologi dan Toksikologi Fakultas Farmasi Universitas Sumatera Utara. Hewan percobaan yang digunakan adalah marmot jantan dewasa dengan berat badan 400-600 gr. Hewan percobaan berada di laboratorium Farmakologi dan Terapeutik, Fakultas Farmasi USU, Medan dengan temperatur sama dengan suhu kamar, kelembaban kira-kira $60 \%$ dan ditempatkan dalam kandang yang terbuat dari Polycarbonat.

Semua hewan percobaan diberi makanan yang berisi nutrisi yang cukup untuk setiap hewan. Ruang laboratorium dijaga dalam siklus siang dan malam. Satu malam sebelum percobaan marmot dipuasakan dan hanya diberi air secukupnya. Percobaan dilakukan dengan memberikan marmot dengan ekstrak air KBM dan ekstrak ethanol KBM berupa perkolat melalui sistem perkolasi. Sampel percobaan dibagi dalam dua kelompok, yakni kelompok kombinasi antara satu antagonis dan kelompok kombinasi antara satu agonis. 


\section{HASIL DAN PEMBAHASAN}

\section{Hasil Uji terhadap Ekstrak Air KBM}

Acethylcholin Klorida sebagai agonis yang berfungsi merangsang kerja reseptor sinaptik pada ileum sehingga meningkatkan peristaltik ileum. Dosis yang diberikan dimulai dari dosis terendah yaitu $10^{-3}$ sampai dosis tertinggi $10^{3}$. Hasil uji yang diperoleh ditunjukkan pada grafik berikut:

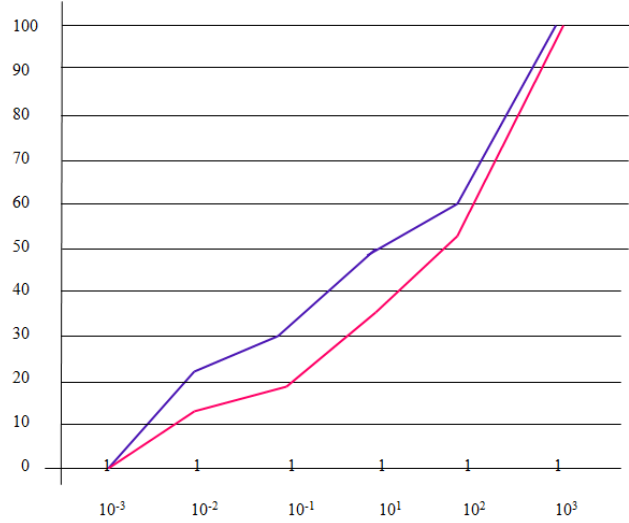

Gambar 1. Uji Acethylcholin Klorida dan Atropin Sulfat+Acethylcholin Klorida (EA1)

Hasil Uji Acethylcholin Klorida (garis ungu) pada dosis $10^{-3}=0,10^{-2}=22,10^{-1}=30,10^{1}=50,10^{2}=60$ dan $10^{3}=100$, merupakan grafik standar agonis dengan grafik antagonis+agonis dan Atropin Sulfat+Acethylcholin Klorida (garis medah muda) pada dosis $10^{-3}=0,10^{-2}=14,10^{-1}=20,10^{1}=38$, $10^{2}=52,10^{3}=100$, merupakan grafik hasil dari antagonis+agonis. Pada garis grafik diatas diketahui bahwa Acethylcholin lebih tinggi dibandingkan dengan garis grafik Atropin sulfat+Acethylcholin Klorida.

Acethylcholin Klorida sebagai agonis yang berfungsi merangsang kerja reseptor sinaptik pada ileum sehingga meningkatkan peristaltik ileum. Dosis yang diberikan dimulai dari dosis terendah yaitu $10^{-3}$ sampai dosis tertinggi $10^{3}$. Hasil uji yang diperoleh ditunjukkan dalam grafik berikut.

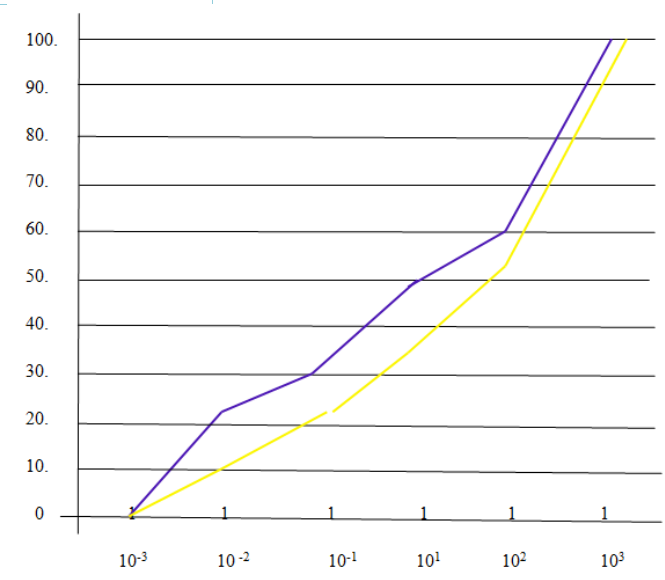

Gambar 2. Uji Acethylcholin Klorida dan Ekstrak Air KBM + Acethylcholin Klorida (EA2)

Hasil uji Acethylcholin Klorida (grafik biru) pada dosis $10^{-3}=0,10^{-2}=22,10^{-1}=30,10^{1}=50$, $10^{2}=60$ dan $10^{3}=100$, merupakan grafik standar agonis dengan grafik antagonis+agonis dan Ekstrak Air+Acethylcholin Klorida (grafik kuning) pada dosis $10^{-3}=0,10^{-2}=10,10^{-1}=21,10^{1}=36$, $10^{2}=51,10^{3}=100$, merupakan grafik hasil dari antagonis+agonis. Pada garis grafik diatas diketahui bahwa Acethylcholin lebih tinggi dibandingkan dengan garis grafik Ekstrak Air $\mathrm{KBM}+$ Acethylcholin.

Histamin Dihydroklorida sebagai agonis yang berfungsi merangsang kerja reseptor sinaptik pada ileum sehingga meningkatkan peristaltik ileum. Dosis yang diberikan dimulai dari dosis terendah yaitu $10^{-3}$ sampai dosis tertinggi $10^{3}$. Hasil uji yang diperoleh ditunjukkan dalam grafik berikut:

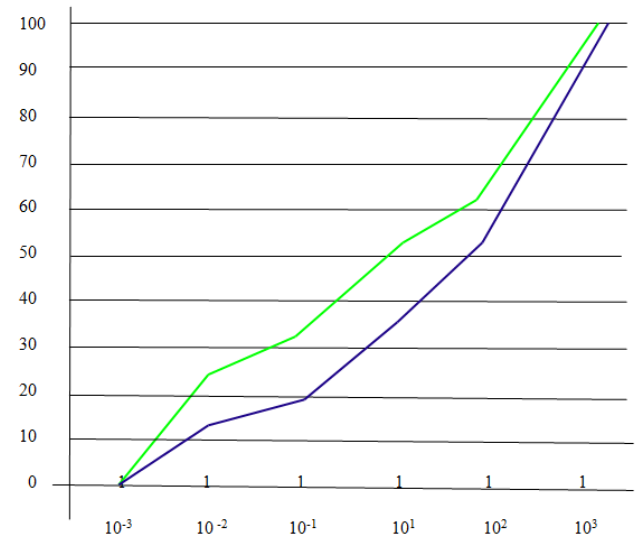

Gambar 3. Uji Histamin Dihydroklorida dan Diphenhidramin Hydroklorida+Histamin Dihydroklorida (EA3) 


\begin{tabular}{|c|r|c}
\hline Jurnal Penelitian Farmasi Herbal & Vol. 2 No. 1 & Edition: May - October 2019 \\
\hline \multirow{2}{*}{ Received: 17 September 2019} & http://ejournal.delihusada.ac.id/index.php/JPFH & Accepted: 14 October 2019 \\
\cline { 2 - 3 } & Revised: 01 October 2019 &
\end{tabular}

Hasil uji Histamin Dihydroklorida (grafik hijau) pada dosis $10^{-3}=0,10^{-2}=25,10^{-1}=32$, $10^{1}=52,10^{2}=62$ dan $10^{3}=100$, merupakan grafik standar agonis dengan grafik antagonis+agonis dan Diphenhidramin Hydroklorida+Histamin Dihydroklorida (grafik biru) pada dosis $10^{-3}=0$, $10^{2}=13, \quad 10^{-1}=20, \quad 10^{1}=36,10^{2}=52, \quad 10^{3}=100$, merupakan grafik hasil dari antagonis+agonis. Pada garis grafik diatas diketahui bahwa Histamin Dihydroklorida lebih tinggi dibandingkan dengan garis grafik Diphenhidramin Hydroklorida+ Histamin Dihydroklorida.

Histamin Dihydroklorida sebagai agonis yang berfungsi merangsang kerja reseptor sinaptik pada ileum sehingga meningkatkan peristaltik ileum. Dosis yang diberikan dimulai dari dosis terendah yaitu $10^{-3}$ sampai dosis tertinggi $10^{3}$. Hasil uji yang diperoleh ditunjukkan dalam grafik berikut:

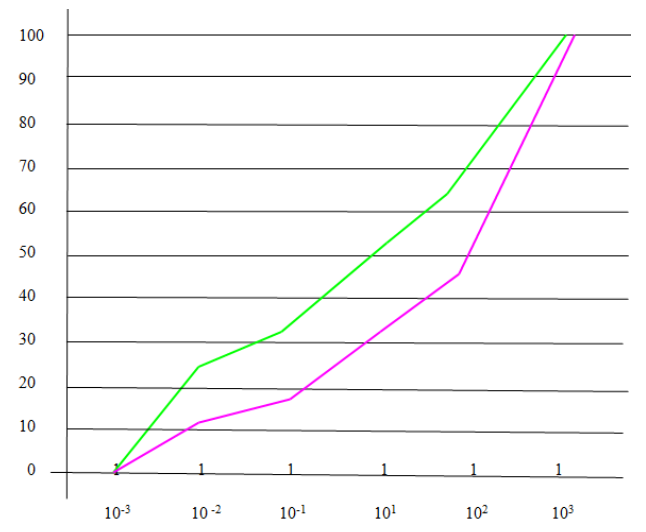

Gambar 4. Data Histamin Dihydroklorida dan Ekstrak Air KBM+Histamin Dihydroklorida (EA4)

Hasil uji Histamin Dihydroklorida (grafik hijau muda) pada dosis $10^{-3}=0,10^{-2}=25,10^{-1}=32$, $10^{1}=52,10^{2}=62$ dan $10^{3}=100$, merupakan grafik standar agonis dengan grafik antagonis+agonis dan uji Ekstrak Air KBM+Histamin Dihydroklorida (grafik merah muda) pada dosis $10^{-3}=0,10^{-2}=11$, $10^{-1}=17,10^{1}=33,10^{2}=48,10^{3}=100$, merupakan grafik hasil dari antagonis+agonis. Pada garis grafik diatas diketahui bahwa Histamin Dihydroklorida lebih tinggi dibandingkan dengan garis grafik Diphenhidramin Hydroklorida+ Histamin Dihydroklorida.

Barrium Klorida sebagai agonis yang berfungsi merangsang kerja reseptor sinaptik pada ileum sehingga meningkatkan peristaltik ileum. Dosis yang diberikan dimulai dari dosis terendah yaitu $10^{-3}$ sampai dosis tertinggi $10^{3}$. Hasil uji yang diperoleh ditunjukkan pada grafik berikut:

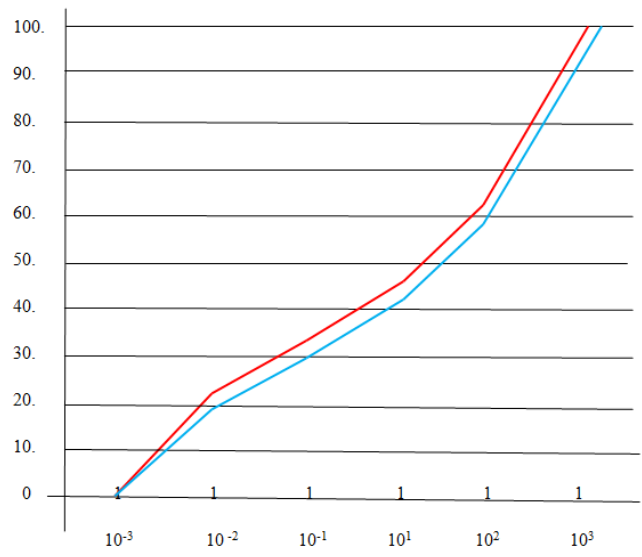

Gambar 5. Uji Barrium Klorida dan Papaverin Hydroklorida+Barrium Klorida (EA5)

Hasil Uji Barrium Klorida (grafik merah) pada dosis $10^{-3}=0,10^{-2}=23,10^{-1}=32,10^{1}=48$, $10^{2}=62$ dan $10^{3}=100$, merupakan grafik standar agonis dengan grafik antagonis+agonis dan uji Papaverin Hydroklorida+Barrium Klorida (grafik biru muda) pada dosis $10^{-3}=0,10^{-2}=20,10^{-1}=30$, $10^{1}=41,10^{2}=59,10^{3}=100$, merupakan grafik hasil dari antagonis+agonis. Pada garis grafik diatas diketahui bahwa Barrium Klorida lebih tinggi dibandingkan dengan garis grafik Papaverin Hydroklorida+Barrium Klorida.

Barrium Klorida sebagai agonis yang berfungsi merangsang kerja reseptor sinaptik pada ileum sehingga meningkatkan peristaltik ileum. Dosis yang diberikan dimulai dari dosis terendah yaitu $10^{-3}$ sampai dosis tertinggi $10^{3}$. Hasil uji yang diperoleh diperlihatkan pada grafik berikut:

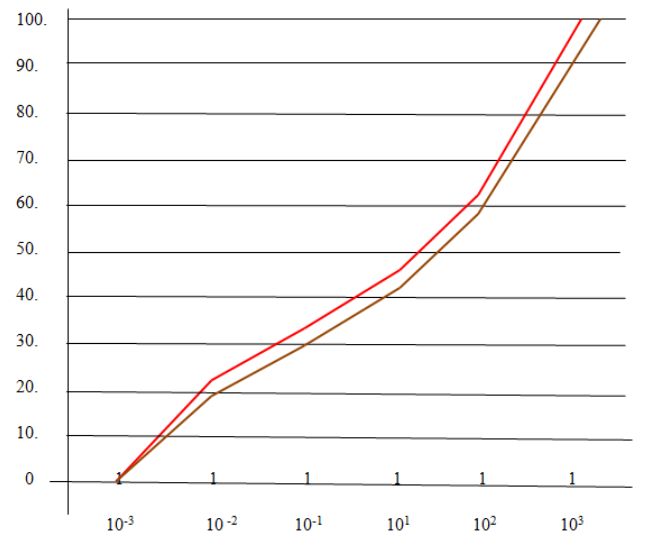

Gambar 6. Uji Barrium Klorida dan Ekstrak Air KBM+Barrium Klorida (EA6) 


\begin{tabular}{c|c|c}
\hline Jurnal Penelitian Farmasi Herbal & Vol. 2 No. 1 & Edition: May - October 2019 \\
\hline & http://ejournal.delihusada.ac.id/index.php/JPFH & \\
\cline { 2 - 3 } Received: 17 September 2019 & Revised: 01 October 2019 & Accepted: 14 October 2019
\end{tabular}

Hasil uji Barrium Klorida (grafik merah) pada dosis $10^{-3}=0,10^{-2}=23,10^{-1}=32,10^{1}=48$, $10^{2}=62$ dan $10^{3}=100$, merupakan grafik standar agonis dengan grafik antagonis+agonis dan uji Ekstrak Air KBM+Barrium Klorida (grafik coklat) pada dosis $10^{-3}=0,10^{-2}=20,10^{-1}=30,10^{1}=41$, $10^{2}=59,10^{3}=100$, merupakan grafik hasil dari antagonis+agonis. Pada garis grafik diatas diketahui bahwa Barrium Klorida lebih tinggi dibandingkan dengan garis grafik Ekstrak Air KBM+Barrium Klorida.

\section{Hasil Uji Terhadap Ekstrak Ethanol KBM}

Acethylcholin Klorida sebagai agonis yang berfungsi merangsang kerja reseptor sinaptik pada ileum sehingga meningkatkan peristaltik ileum. Dosis yang diberikan dimulai dari dosis terendah yaitu $10^{-3}$ sampai dosis tertinggi $10^{3}$. Hasil uji yang diperoleh diperlihatkan pada grafik berikut:

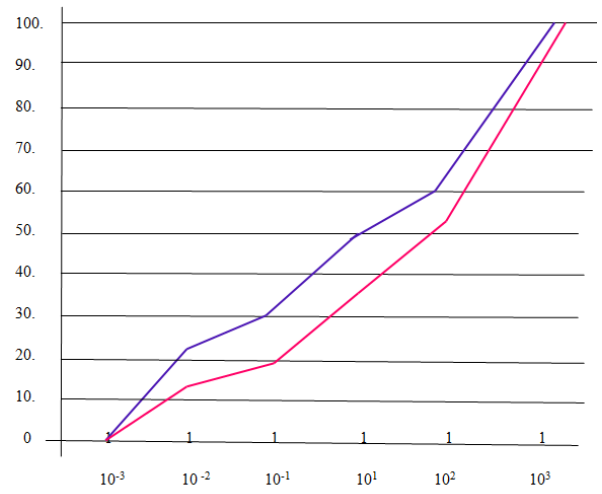

Gambar 7. Uji Acethylcholin Klorida dan Atropin Sulfat + Acethylcholin Klorida ( EE1 )

Hasil uji Acethylcholin Klorida (grafik biru) pada dosis $10^{-3}=0,10^{-2}=22,10^{-1}=30,10^{1}=50$, $10^{2}=60$ dan $10^{3}=100$, merupakan grafik standar agonis dengan grafik antagonis+agonis dan uji Atropin Sulfat+Acethylcholin Klorida (grafik merah muda) pada dosis $10^{-3}=0,10^{-2}=14,10^{-1}=20$, $10^{1}=38,10^{2}=52,10^{3}=100$, merupakan grafik hasil dari antagonis+agonis. Pada garis grafik diatas diketahui bahwa Acethylcholin lebih tinggi dibandingkan dengan garis grafik Atropin sulfat+ Acethylcholin Klorida.

Acethylcholin Klorida sebagai agonis yang berfungsi merangsang kerja reseptor sinaptik pada ileum sehingga meningkatkan peristaltik ileum. Dosis yang diberikan dimulai dari dosis terendah yaitu $10^{-3}$ sampai dosis tertinggi $10^{3}$. Hasil uji yang diperoleh diperlihatkan pada grafik berikut:

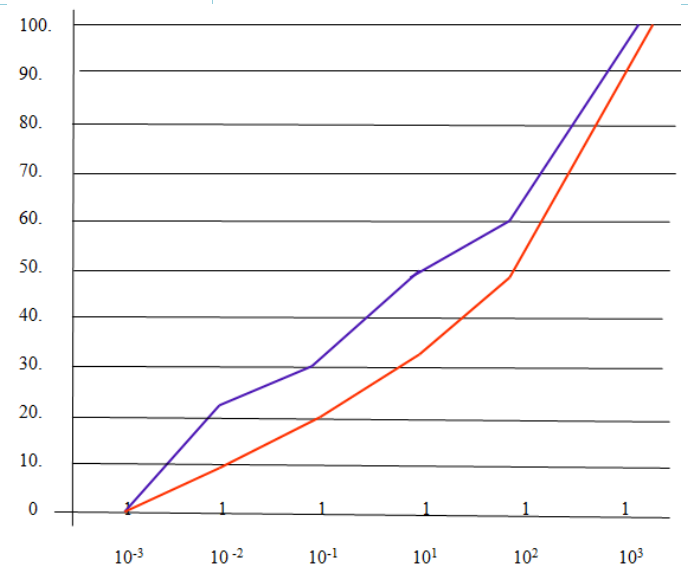

Gambar 8. Uji Acethylcholin Klorida dan Ekstrak Ethanol KBM+Acethylcholin Klorida (EE2)

Hasil uji Acethylcholin Klorida (grafik biru) pada dosis $10^{-3}=0,10^{-2}=22,10^{-1}=30,10^{1}=50$, $10^{2}=60$ dan $10^{3}=100$, merupakan grafik standar agonis dengan grafik antagonis+agonis dan uji Ekstrak Ethanol KBM+Acethylcholin Klorida (grafik medah) pada dosis $10^{-3}=0,10^{-2}=10,10^{-1}=20$, $10^{1}=32,10^{2}=49,10^{3}=100$, merupakan grafik hasil dari antagonis+agonis. Pada garis grafik diatas diketahui bahwa Acethylcholin lebih tinggi dibandingkan dengan garis grafik Ekstrak Ethanol+Acetylcholin Klorida.

Histamin Dihydroklorida sebagai agonis yang berfungsi merangsang kerja reseptor sinaptik pada ileum sehingga meningkatkan peristaltik ileum. Dosis yang diberikan dimulai dari dosis terendah yaitu $10^{-3}$ sampai dosis tertinggi $10^{3}$. Hasil uji yang diperoleh ditunjukkan pada grafik berikut:

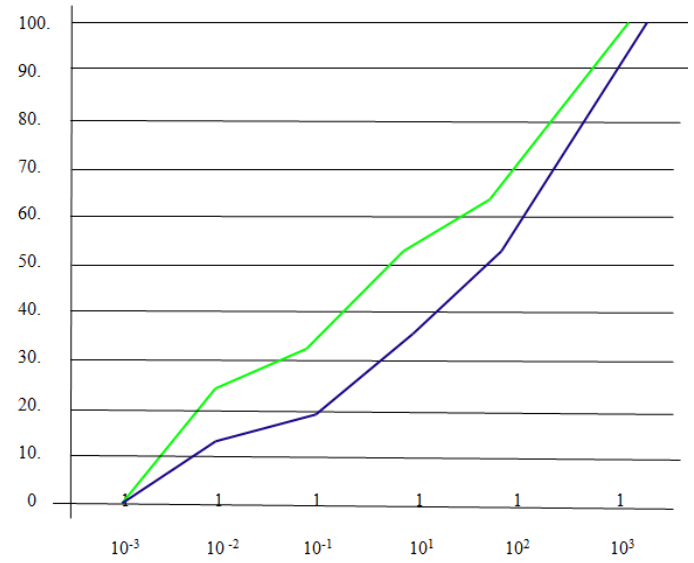

Gambar 9. Uji Histamin Dihydroklorida dan Diphenhidramin Hydroklorida+Histamin Dihydroklorida (EE3)

Hasil uji Histamin Dihydroklorida (grafik hijau) pada dosis $10^{-3}=0,10^{-2}=25,10^{-1}=32$, 


\begin{tabular}{c|c|c}
\hline Jurnal Penelitian Farmasi Herbal & Vol. 2 No. 1 & Edition: May - October 2019 \\
\hline & http://ejournal.delihusada.ac.id/index.php/JPFH & \\
\cline { 2 - 3 } Received: 17 September 2019 & Revised: 01 October 2019 & Accepted: 14 October 2019
\end{tabular}

$10^{1}=52,10^{2}=62$ dan $10^{3}=100$, merupakan grafik standar agonis dengan grafik antagonis+agonis dan Diphenhidramin Hydroklorida+Histamin Dihydroklorida (grafik biru) paddosis $10^{-3}=0$, $10^{-2}=13, \quad 10^{-1}=20, \quad 10^{1}=36,10^{2}=52,10^{3}=100$, merupakan grafik hasil dari antagonis+agonis. Pada garis grafik diatas diketahui bahwa Histamin Dihydroklorida lebih tinggi dibandingkan dengan garis grafik Diphenhidramin Hydroklorida+ Histamin Dihydroklorida.

Histamin Dihydroklorida sebagai agonis yang berfungsi merangsang kerja reseptor sinaptik pada ileum sehingga meningkatkan peristaltik ileum. Dosis yang diberikan dimulai dari dosis terendah yaitu $10^{-3}$ sampai dosis tertinggi $10^{3}$. Hasil uji yang diperoleh ditunjukkan pada grafik berikut:

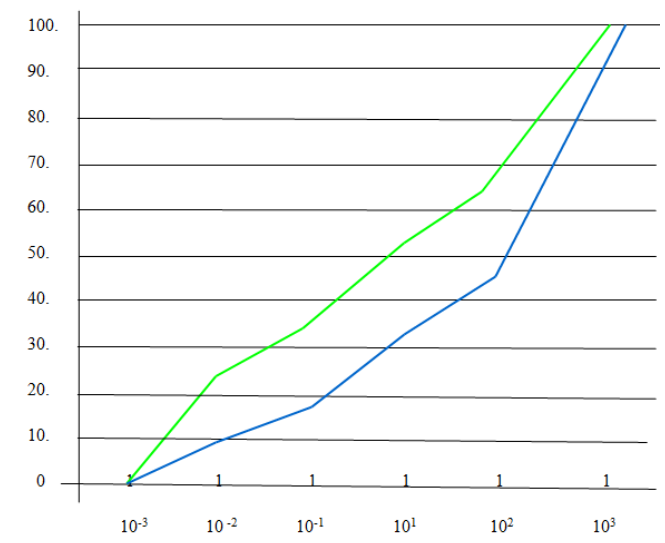

Gambar 10. Uji Histamin Dihydroklorida dan Ekstrak Ethanol KBM+Histamin Dihydroklorida (EE4)

Hasil uji Histamin Dihydroklorida (grafik hijau) pada dosis $10^{-3}=0,10^{-2}=25,10^{-1}=32$, $10^{1}=52,10^{2}=62$ dan $10^{3}=100$, merupakan grafik standar agonis dengan grafik antagonis+agonis dan uji Ekstrak Ethanol KBM+Histamin Dihydroklorida (grafik hijau) pada dosis $10^{-3}=0$, $10^{-2}=10,10^{-1}=18,10^{1}=32,10^{2}=46,10^{3}=100$, merupakan grafik hasil dari antagonis+agonis. Pada garis grafik diatas diketahui bahwa Histamin Dihydroklorida lebih tinggi dibandingkan dengan garis grafik Ekstrak Ethanol KBM+Histamin Dihydroklorida.

Barrium Klorida sebagai agonis yang berfungsi merangsang kerja reseptor sinaptik pada ileum sehingga meningkatkan peristaltik ileum. Dosis yang diberikan dimulai dari dosis terendah yaitu $10^{-3}$ sampai dosis tertinggi $10^{3}$.
Hasil uji yang diperoleh ditunjukkan pada grafik berikut:

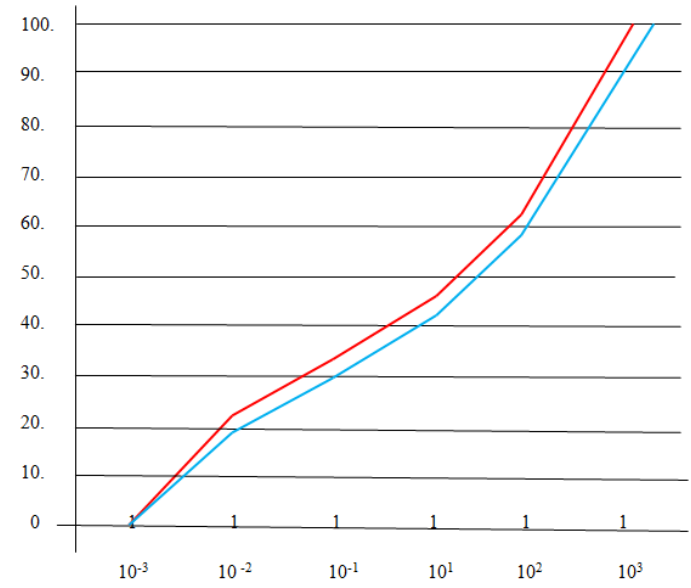

Gambar 11. Uji Barrium Klorida dan Papaverin Hydroklorida + Barrium Klorida (EE5)

Hasil uji Barrium Klorida (grafik merah) pada dosis $10^{-3}=0,10^{-2}=23,10^{-1}=32,10^{1}=48$, $10^{2}=62$ dan $10^{3}=100$, merupakan grafik standar agonis dengan grafik antagonis+agonis dan uji Papaverin Hydroklorida+Barrium Klorida (grafik biru muda) pada dosis $10^{-3}=0,10^{-2}=20,10^{-1}=30$, $10^{1}=41,10^{2}=59,10^{3}=100$, merupakan grafik hasil dari antagonis+agonis. Pada garis grafik diatas diketahui bahwa Barrium Klorida lebih tinggi dibandingkan dengan garis grafik Papaverin Hydroklorida+Barrium Klorida

Barrium Klorida sebagai agonis yang berfungsi merangsang kerja reseptor sinaptik pada ileum sehingga meningkatkan peristaltik ileum. Dosis yang diberikan dimulai dari dosis terendah yaitu $10^{-3}$ sampai dosis tertinggi $10^{3}$. Hasil uji yang diperoleh diperlihatkan pada grafik berikut:

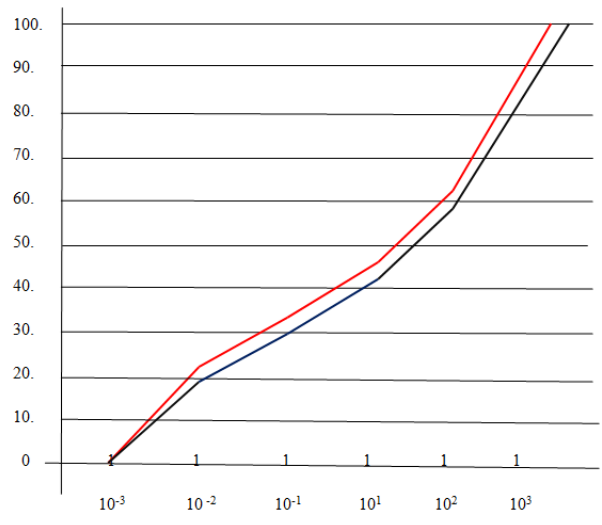

Gambar 12. Uji Barrium Klorida dan Ekstrak Ethanol KBM + Barrium Klorida (EE6) 


\begin{tabular}{c|c|c}
\hline Jurnal Penelitian Farmasi Herbal & Vol. 2 No. 1 & Edition: May - October 2019 \\
\hline & http://ejournal.delihusada.ac.id/index.php/JPFH & \\
\cline { 2 - 2 } Received: 17 September 2019 & Revised: 01 October 2019 & Accepted: 14 October 2019 \\
\hline
\end{tabular}

Hasil uji Barrium Klorida (grafik merah) pada dosis $10^{-3}=0,10^{-2}=23,10^{-1}=32,10^{1}=48$, $10^{2}=62$ dan $10^{3}=100$, merupakan grafik standar agonis dengan grafik antagonis+agonis dan uji Ekstrak Ethanol KBM+Barrium Klorida (grafik biru) pada dosis $10^{-3}=0,10^{-2}=20,10^{-1}=30,10^{1}=41$, $10^{2}=59,10^{3}=100$, merupakan grafik hasil dari antagonis+agonis. Pada garis grafik diatas diketahui bahwa Barrium Klorida lebih tinggi dibandingkan dengan garis grafik Ekstrak Ethanol KBM+Barrium Klorida.

\section{Uji Perbedaan Kandungan}

Setelah melakukan uji kandungan ekstrak KBM diperoleh dua kelompok ekstrak air yang ditunjukkan oleh tabel 1 berikut.

Tabel 1. Perbedaan Kontraksi Ileum I

\begin{tabular}{clccc}
\hline No & Perlakuan & $\mathbf{n}$ & $\mathbf{X} \pm$ SD & P \\
\hline 1 & Ach (A) & 6 & $43,666 \pm 14,576$ & \\
2 & Atp + Ach & 6 & $37,333 \pm 10,768$ & .099 \\
3 & Ach (B) & 6 & $43,666 \pm 14,576$ & \\
4 & EE + Ach & 6 & $35,166 \pm 9,985$ & \\
\hline
\end{tabular}

Keterangan:

Ach adalah Acethylcholin Klorida

Atp adalah Atropin Sulfat

EE adalah Ekstrak Ethanol KBM

Tabel 1 di atas menunjukkan bahwa tidak ada perbedaan rata-rata kontraksi ileum yaitu 43,666 pada Ach (A) dan 43,666 pada Ach (B), dengan tidak memiliki selisih yang berarti $(P=$ $0,00)$. Dari hasil tersebut, Ach $(A)$ dan Ach (B) memiliki kontraksi yang sama terhadap peristaltik ileum, sedangkan pada Atp+Ach dan EE+Ach menunjukkan terdapat perbedaan rata-rata kontraksi ileum dengan selisih 2,166 (yaitu hasil $37,333-35,166$ ) dengan $p$ sebesar 0,099 >0,05. Ini artinya bahwa Atp dan Ekstrak Ethanol KBM menurunkan kontraksi ileum, tetapi dalam hal ini Atp lebih kuat daya penurunan kontraksi ileum dibandingkan dengan Ekstrak Ethanol KBM.

Tabel 2. Perbedaan Kontraksi Ileum II

\begin{tabular}{clccc}
\hline No & Perlakuan & $\mathbf{n}$ & $\mathbf{X} \pm$ SD & P \\
\hline 1 & His (A) & 6 & $43,166 \pm 15,376$ & \\
2 & Dip + His & 6 & $36,833 \pm 10,498$ & \\
3 & His (B) & 6 & $43,166 \pm 15,385$ & .089 \\
4 & EE + His & 6 & $34,333 \pm 9,295$ & \\
\hline
\end{tabular}

\section{Keterangan:}

His adalah Histamin Dihydroklorida

Dip adalah Diphenhidramin Hydroklorida

EE adalah Ekstrak Ethanol KBM
Tabel 2 di atas menunjukkan bahwa tidak ada perbedaan rata-rata kontraksi ileum yaitu 43,166 pada His (A) dan 43,166 pada His (B) dengan tidak memiliki selisih yang berarti $(P=$ $0,00)$. Dari hasil tersebut menunjukkan His $(A)$ dan His (B) memiliki pengaruh kontraksi yang sama terhadap peristaltik ileum, sedangkan pada $\mathrm{Dip}+\mathrm{His}$ dan $\mathrm{EA}+\mathrm{His}$ menunjukkan terdapat perbedaan rata-rata kontraksi ileum dengan selisih 2,5 (yaitu hasil 36,833 - 34,333) dengan $\mathrm{p}$ sebesar $0,089>0,05$. Dari hasil tersebut menunjukkan bahwa Dip dan Ekstrak Ethanol KBM menurunkan kontraksi ileum, tetapi dalam hal ini Dip lebih kuat daya penurunan kontraksi ileum dibandingkan dengan Ekstrak Ethanol KBM.

Tabel 3. Uji Perbedaan Rata-rata Selisih Kontraksi Ileum

\begin{tabular}{clccc}
\hline No & \multicolumn{1}{c}{ Perlakuan } & $\mathbf{n}$ & $\mathbf{X} \pm$ SD & P \\
\hline 1 & Ach - Atp + Ach & 6 & $6,333 \pm 3,808$ & \\
2 & Ach - EE + Ach & 6 & $8,500 \pm 4,591$ & \\
3 & His - Dip + His & 6 & $8,333 \pm 4,878$ & .032 \\
4 & His - EE + His & 6 & $10,83 \pm 6,090$ & \\
5 & Bar - Papa + Bar & 6 & $2,500 \pm 1,740$ & \\
6 & Bar - EE + Bar & 6 & $2,500 \pm 1,740$ & \\
\hline
\end{tabular}

Keterangan:

Ach adalah Acethylcholin Klorida

Atp adalah Atropin Sulfat

His adalah Histamin Dihydroklorida

Dip adalah Diphenhidramin Hydroklorida

EE adalah Ekstrak Ethanol KBM

Bar adalah Barrium Klorida

Papa adalah Papaverin Hydroklorida

Hasil uji pada tabel 3. di atas menunjukkan bahwa adanya selisih:

1. Kontraksi ileum dalam Ach dengan Atp+Ach (1) yaitu 6,333 dibandingkan selisih kontraksi ileum Ach dengan EE+Ach (2) yaitu 8,500 dengan selisih keduanya 2,167 di mana $\mathrm{P}>$ 0.05 , artinya perbedaan selisih kedua kontraksi ileum tersebut signifikan.

2. Kontraksi ileum dalam His dengan Dip+His (3) yaitu 8,333 dibandingkan selisih kontraksi ileum His dengan $\mathrm{EE}+\mathrm{His}$ (4) yaitu 10,833 dengan selisih keduanya 2,5 di mana $P>$ 0.05 , artinya perbedaan selisih kedua kontraksi ileum tersebut signifikan.

3. Kontraksi ileum dalam Bar dengan Papa+Bar (5) yaitu 2,500 dibandingkan selisih kontraksi ileum Bar dengan EE+Bar (6) yaitu 2,500 tidak ada selisih dari keduanya mana $P=0.00$, artinya tidak ada perbedaan selisih kedua kontraksi ileum tersebut. Ini menunjukkan 


\begin{tabular}{c|c|c}
\hline Jurnal Penelitian Farmasi Herbal & Vol. 2 No. 1 & Edition: May-October 2019 \\
\hline & http://ejournal.delihusada.ac.id/index.php/JPFH & \\
\cline { 2 - 3 } Received: 17 September 2019 & Revised: 01 October 2019 & Accepted: 14 October 2019
\end{tabular}

Ekstrak Ethanol KBM ada kemiripan kerjanya dengan Papaverin Hydroklorida, hal ini dianggap signifikan.

Dari ketiga kelompok percobaan di atas maka dapat disimpulkan bahwa Ekstrak Ethanol Kulit Buah Manggis bekerja mirip dengan Papaverin Hydroklorida.

Dari hasil ujicoba pada tabel 1 . menunjukkan bahwa Atropin sulfat dan ekstrak Ethanol KBM menurunkan kontraksi ileum, tetapi dalam hal ini Atp lebih kuat daya penurunan kontraksi ileum dibandingkan dengan ekstrak air KBM. Acethylcholin Klorida adalah bahan kimia organik yang berfungsi di otak sebagai neuro transmitter, pesan kimiawi yang dilepaskan oleh sel saraf untuk mengirim sinyal ke sel neuron, sel otot dan sel kelenjar yang dapat berfungsi meningkatkan peristaltik usus (Picciotto, 2012).

Atropin Sulfat termasuk golongan anti kolinergik yang bekerja pada reseptor muskarinik (anti muskarinik), menghambat transmisi acethylcholin yang di persarafi oleh serabut pasca ganglioner kolinergik. Selain itu, atropin sulfat merupakan antispasmodik yang mampu memblok asetilkolin di perifer pada usus yang berpotensi sebagai karminatif, antidiare dan juga antispasmodik (Sriyani, 2016).

Hasil skrining fitokimia yang dilakukan terhadap ekstrak etanol kulit buah manggis (Garcinia mangostana L.) telah terbukti memiliki berbagai macam aktivitas farmakologi (Dewi, 2013) seperti histamin dihydroklorida yang berfungsi sebagai stimulan sekresi asam lambung yang kuat, konstriktor otot polos bronkial, vasodilator dan neuro transmitter yang bekerja sentral dan meningkatkan peristaltik usus (Greiner, 2012).

Diphenhidramin Hydroklorida adalah obat yang termasuk golongan anti histamin. Obat ini bekerja dengan memblok efek bahan kimia tertentu seperti histamin penyebab gatal dan memblok reseptor parasimpatik sehingga kerja saraf parasimpatik menurun atau terhambat. Peristaltik meninggi yang disebabkan oleh karena rangsangan parasimpatik direseptor usus dapat menurun atau diblok dengan pemberian Diphenhidramin Hydroklorida (Novita J, 2015). Histamin Dihydroklorida merupakan senyawa amina basa yang dibentuk dari asam amino histidin dengan bantuan enzim L-Histidin dekarboksilase yang bekerja meningkatkan peristaltik usus (Agung, 2011).

Ada hubungan usus dengan otak, karena stres memberikan impuls-impuls ke usus untuk meningkat gerakan peristaltiknya. Meningkatnya gerakan peristaltik bisa menyebabkan diare. Berdasarkan hasil uji yang dilakukan terhadap ekstrak ethanol KBM, diketahui bahwa terdapat kandungan zat seperti acethylcholin klorida, atropin sulfat, histamin dihydroklorida, diphenhidramin hydroklorida yang setara dengan Papaverin Hydroklorida yang mampu mengurangi gerak peristaltik usus sehingga mengurangi gejala diare.

\section{KESIMPULAN}

Dari ketiga kelompok percobaan di atas maka dapat disimpulkan bahwa Ekstrak Ethanol Kulit Buah Manggis bekerja mirip dengan Papaverin Hydroklorida yang merupakan obat antidiare yang digunakan untuk melemaskan otot-otot polos, sehingga juga dapat membuat pembuluh darah melebar dengan melemaskan otot polos pada dinding pembuluh darah.

\section{DAFTAR PUSTAKA}

Adnyana, Ketut. et.al. 2004. Efek Ekstrak Daun Jambu Biji Daging Buah Putih dan Jambu Biji Daging Buah Merah sebagai Antidiare. Bandung: Institut Teknologi Bandung.

Agung E.N. 2011. Antagonisme Marmin Terhadap Reseptor 5-Hidroksi Triptamin dan Reseptor Histamin pada Otot Polos Ileum Marmot. Jogyakarta: Universitas Gadjah Mada. http://www.fmipa.ac.id.ugm.08052019

Anas, Y., Hidayati, D.N., Kurniasih, A., \& Ksatria, D.S.L. 2016. Aktivitas Antidiare Ekstrak Etanol Daun Nangka (Artocarpus Heterophyllus Lam.) Dan Daun Angsana (Pterocarpus Indicus Wild.) Pada Mencit Jantan Galur Balb/c. Jurnal Ilmu Farmasi dan Farmasi Klinik, Vol. 13 (1).

Burkill, H.M. 1997. The Useful Plants of West Tropical Africa: Families M-R. Michigan: Royal Botanic Gardens, Michigan University 


\begin{tabular}{c|c|c}
\hline Jurnal Penelitian Farmasi Herbal & Vol. 2 No. 1 & Edition: May - October 2019 \\
\hline & http://ejournal.delihusada.ac.id/index.php/JPFH & \\
\cline { 2 - 2 } Received: 17 September 2019 & Revised: 01 October 2019 & Accepted: 14 October 2019 \\
\hline
\end{tabular}

Dewi, I.D.A.D.Y, Astuti, K.W., \& Warditiani, N.K. 2013. Identifikasi Kandungan Kimia Ekstrak Kulit Buah Manggis (Garcinia Mangostana L.). Jurnal Farmasi Udayana, Vol. 2 (4).

Dinas Kesehatan. 2016a. Profil Kesehatan Medan Tahun 2016. Medan: Dinas Kesehatan Kota Medan, Subbidang Program, Informasi dan Hubungan Masyarakat

Dinas Kesehatan. 2016b. Profil Kesehatan Sumut Tahun 2016. Medan: Dinas Kesehatan Provinsi Sumatera Utara.

Galvez, J., Zarzuelo, A., Crespo, M.E., Utrilla, M.P., Jiménez, J., Spiessens, C. and Witte, P.D. 1991. Antidiarrhoeic Activity of Sclerocarya birrea Bark Extract and Its Active Tannin Constituent in Rats, Phytother. Res. 5, 6, 276278.

Greiner, J. 2012. Maintenence Therapy With Histamin Dihydroklorida. Universitas ULM: Nasional Library of Medicine. http://www.pubcehem.ncbi.nlm.nil.gov.110 $\underline{52019}$

Hudayani, M. 2008. Efek Antidiare Ekstrak Etanol Rimpang Kunyit (Curcuma Domestica Val.) Pada Mencit Jantan Galur Swiss Webster. (Skripsi tidak diterbitkan). Surakarta: Universitas Muhammadiyah Surakarta.

Kumar, B., Divakar, K., Tiwari, P., Salhan, M. and Goli, D., 2010 , Evaluation of AntiDiarrhoeal Effect of Aqueous and Ethanolic Extracts of Fruit Pulp of Terminalia belerica in Rats, IJDDR, 2, 4, 769-779.

Miryanti, A., Sapei, L., Budiono, K., \& Indra, S. 2011. Ekstraksi Antioksidan dari Kulit Buah Manggis (Garcinia Mangostana L.). (Laporan penelitian tidak diterbitkan). Bandung: Universitas Katolik Parahyangan.

Musdar, T.A. 2012. Uji Aktivitas Anti Diare Ekstrak Etanol Daun Salam (Poliyanthi Folium) Pada Mencit (Mus Musculus) yang di Induksi Oleum Ricini. (Skripsi tidak diterbitkan). Makasar: UIN Alauddin Makasar.

Mutschler, E., 1991, Dinamika Obat, diterjemahkan oleh Mathilda B.W. \& Anna S.R. Bandung: Institut Teknologi Bandung.
Noviardini, P.U. 2010. Uji Aktivitas Antibakteri Alfa Mangostin Kulit Buah Manggis (Garcinia Mangostana L.) Terhadap Bakteri Escherichia Coli Multiresisten Antibiotik Dan Bakteri Streptococcus Sp. (Skripsi tidak diterbitkan). Surakarta: Universitas Muhammadiyah Surakarta.

Novita J. 2014. Aktifitas Diphenhidramin Hydroklorida Pada Ileum Marmot. Padang: Fakultas Farmasi, Universitas Andalas. http://www.fmipa.ac.id.unand.09052019

Pamungkas, S.D.C. 2009. Efek Antidiare Infusa Kulit Batang Jambu Mede (Anarcardiae Cortex) Pada Mencit Putih Betina dengan Metode Transit Intestinal. (Skripsi tidak diterbitkan). Yogyakarta: Universitas Sanata Dharma.

Picciotto, M.R., Higley, M.J., \& Mineur, Y.S. 2012. Acetylcholine as a Neuromodulator: Cholinergic Signaling Shapes Nervous System Function and Behavior. Neuron 76, October 4, 2012.

Putra, I.N.K. 2010. Aktivitas Antibakteri Ekstrak Kulit Buah Manggis (Garcinia Mangostana L.) serta Kandungan Senyawa Aktifnya. Jurnal Teknologi dan Industri Pangan, Vol. 21 (1).

Rubiyanti, R., Susilawati, Y., \& Muchtaridi. 2017. Potensi Ekonomi dan Manfaat Kandungan Alfa-Mangostin serta Gartanin dalam Kulit Buah Manggis (Garcinia Mangostana Linn) Economic and Benefits Potential AlfaMangostin Gartanin in Rindmangosteen (Garcinia Mangostana Linn). Farmaka, Vol. 15 (1).

Sriyani, D. \& Saputri, F.C. 2016. Pengaruh Pemberian Minyak Atsiri Daun Kemangi (Ocimum americanum L.) Terhadap Motilitas Usus Mencit Putih Jantan. Pharmaceutical Sciences and Research, Vol. 3 (1), p. 21-30.

Tan, H.T, \& Rahardja, K. 2002. Obat-Obat Penting: Khasiat, Penggunaan, Dan Efek Sampingnya, Edisi V. Jakarta: PT Elex Media Komputindo. 


\begin{tabular}{c|c|c}
\hline Jurnal Penelitian Farmasi Herbal & Vol. 2 No. 1 & Edition: May-October 2019 \\
\hline \multirow{2}{*}{ Received: 17 September 2019} & http://ejournal.delihusada.ac.id/index.php/JPFH & \multirow{2}{*}{ Accepted: 14 October 2019} \\
\cline { 2 - 2 } & Revised: 01 October 2019 & \\
\hline
\end{tabular}

Widiyati, E. 2006. Penentuan Adanya Senyawa

Triterpenoid dan Uji Aktivitas Biologis Pada Beberapa Spesies Tanaman Obat Tradisional Masyarakat Pedesaan Bengkulu. Gradien; Jurnal Ilmiah MIPA, Vol. 2 (1).

Yatman, E. 2012. Kulit Buah Manggis Mengandung Xanton Yang Berkhasiat Tinggi. Wawasan, Vol. 29 (324). 